\title{
Some Sports Managers' Views about Values Education through Sports
}

\author{
Velittin Balci ${ }^{1}$, Övünç Erdeveciler ${ }^{1}$ \\ ${ }^{1}$ Faculty of Sport Sciences, Ankara University, Ankara, Turkey \\ Correspondence:Velittin Balc1, Faculty of Sport Sciences, Ankara University, Ankara, Turkey.
}

Received: April 5, 2017

Accepted: April 21, 2017

Online Published: April 24, 2017

doi:10.11114/jets.v5i5.2386

URL: https://doi.org/10.11114/jets.v5i5.2386

\begin{abstract}
The indirect aim of this study is to ensure that sports and participation in sports are seen as new tools for values education. From this indirect goal, it was aimed to analyse the views of some Amateur Sports Club managers and supporters who were supposed to directly contribute to sports and the athletes about values education. The study was planned based on qualitative interview technique. In thematic framework of education values, questions were prepared in the form of semi-structured questionnaire appropriate for qualitative interview technique, and participants in the study were asked to answer these questions voluntarily. The working group formed a total of 41 people consisting of the presidents and vice-chairmen of some Amateur Sports Clubs operating in Ankara. In the findings of interviews made with the mentioned method; it has been observed that managers have prominent values such as 'prestige', 'tolerance', 'communication', 'love', 'sharing', 'diligence', 'health', and 'growing healthy people'. However, in the process of transferring these values to the people they work with, the managers who participated in the study came to the conclusion that their own awareness did not occur sufficiently.
\end{abstract}

As a result, it can be said that there is no single meaning of personal awareness about values education, and some methods and paradigms have to be passed on concerning these universal values' transfer to co-workers. Perhaps getting out of the ordinary for sports managers is like self-renew and likely to change the order of priorities.

Keywords: values education, sports, sports manager

\section{Introduction}

Transfers of generational values to the values that form the basis of social structures are expected and this transfer must take place in a programmed manner. In this sense the value of education has a huge precaution in the concept. The root of values education is based on character education in the United States in the 1920s, and the publication of studies on this education found the 1970s. When the published works were examined, such names as Rokeach, Simon, How, Raths, Harmin, Kirschenbaum, Kohlberg have been the pioneers of this field. (Elbir and Bağc1, 2013)

Values play an important role in shaping attitudes and behaviours at the same time, guiding how individuals need their lives in society. (Akbaş, 2008) Sustainable societies are realized through the preservation of existing value and their preservation. Kerschensteiner (1954) stated that all teams formed by people must develop values (Köybaşı and Dönmez, 2012). At the same time, the fact that values do not have a static structure is the most fundamental reason why the concept of value creates a constantly changing dynamic (Balc1 and Yanpar Yelken, 2010). The perception of values in different ways in different societies confirms the changing face of values.

There is no exact definition of the concept of value that is derived from the effort of various scientists and philosophical thinkers to interpret it. It is also the main reason that every scientific discipline identifies only the self-interested part of the value and ignores the other parts. The words most connected with the concept of value have been beliefs and tendencies. In this case it would be more rational to put the related words instead of defining the concept of value (Ulusoy and Dilmaç 2012).

Kızılçelik, Erjem, 1994 akt. Genç and Eryaman (2008) defined the concept of value as all of the general moral beliefs that reflect common feelings, thoughts, goals and interests accepted by the majority in order to sustain the existence of society or social groups.

Belkin (1988) stated that values have an important place both in terms of individual behaviours affecting individual processes as well as being embedded in the cultural structure of society. Until today values such as "responsibility, equality, justice, freedom, tolerance, motivation, trust, autonomy, ambition, honesty, courage, respect, self-confidence, 
helpfulness, honesty, love, obedience, success" takes the first place. (Çağlar, 2005 akt.: Öztürk Samur, 2011)

Acun et al. (2013), think that behaviours and values acquired by children at an early age will affect their whole future. Therefore, they assert that the education given in the era of primary education plays a major role in the acquisition of these values. To be gained these values, the main job is schools' and families'. For this, school and family should cooperate with and agree on each other, follow their children by observing closely, and show the self-abnegation needed to be acquired these values.

Kafadar (2002) emphasized that educating individuals with social values and at the same time developing these values require great efforts of our education system. Balc1 and Yelken (2010) stated that since educating individuals who have nationality consciousness, are modern, knowledgeable and practicing culture is a fundamental aim of education, a social and cultural meaning have been added to the education system.

Lickona (1991), in a survey he had done, found that a primary school student spends an average of 30 hours a week in front of television and that by the age of 16, the child has witnessed an average of 200,000 violent scenes and approximately 40,000 sexual stimulus by the age of 18 . In order to eliminate these negative effects on students, the values that should be given to them through the curricula have been determined (Yiğittir and Öcal, 2011).

From past to present, societies have used various methods and tools in order to protect and develop their own culture; yet, the effects of all sports and sports related activities on culture cannot be ignored. Roles of values like sports in the integration of individuals and in the provision of social solidarity are very important (Öcalan ve Ramazanoğlu, 2003) Sports also provides the development of these values as it has many attributes in it. It is inevitable that sports which is a sociological phenomenon integrates people as in human nature is a tool for values education.

The sports industry, especially since the beginning of the $20^{\text {th }}$ century, becoming self-empowered and shaping of it on commercial concerns has also been a scene of a decline in moral values. Increasingly, moving away from the philosophy of Fair Play caused the idea to come to the forefront that is "winning at any cost" (Ylldiran I, 2005). The question that what is the role of social values in today's sports, where the desire to win is at the forefront, often comes to foreground. However, the word "fairness" at the root of the notion of "Fair Play" implies to act honestly, to be virtuous, behave bravely and it can be reached the interpretation that this concept is not just for sports (Şebin et al. 2010). At this point, the concept of values and sports intersect because social values are in a dimension that also includes the concept of 'Fair Play'.

Values and values education are discussed with different literature examples above where it is possible to shape education from different directions. We think that it is important to question the basic of approaches to values education and to draw attention to this point, assuming sports is a social communication and education tool and that those who pursue sports education through the clubs and branches. With the values education and sports approach, the aim of this study is to make a question about how sports managers who manage sports clubs in Ankara use value education in their practices.

\section{Method}

Qualitative research design was used in the research. The qualitative research design may allow investigating a selected framework concept. In addition, this method is preferred for collecting data in our work because qualitative research can use qualitative data collection methods such as observation, interview and document analysis, and it can provide an opportunity to identify events and perceptions as a method that investigates a process that includes living things in a holistic and realistic way.

Two forms of interview form were used in the research. The first part consists of demographic information, while the second part consists of structured and semi-structured questions. The interview form to be used was created by the author with help from experts in the field. During the interview, however, participants were given reference information in order to better understand some of the questions and to get deeper insights from the participants.

The schedule of the study includes the competition season of 2016-2017 amateur sports clubs. The working group formed 41 people consisting of the president and vice-chairman of the Amateur Sports Clubs operating in the province of Ankara. Participant names were kept confidential and "P" code was given to club presidents and "VC" to vice presidents. In the research, qualitative research designs are used which are appropriate to the nature of the research. The case is a science design, a research that allows us to research what we are aware of but do not have an in-depth understanding (Yıldırım and Şimşek 2011). The obtained data were analysed and interpreted in qualitative researches by using frequently preferred content analysis method. Before analysing, the categories were determined by the researcher, taking into account the purpose of the study and the program analysis steps. In this work, Belkin's concept of values is defined as "responsibility, equality, justice, freedom, tolerance, respect, motivation, trust, autonomy, ambition, truthfulness, courage, respect, self-confidence, helpfulness, honesty, love, obedience, achievement "and sports managers who have been included in the qualitative study will have determined that they have used at least a few of the notion of 
value according to their answers to their work questions. The resulting themes and codes are organized under these categories.

\section{Findings}

The charts of the information and theme of the amateur sports club presidents and vice-chairmen are given below.

Table 1. General Information about Participants

\begin{tabular}{|c|c|c|c|c|}
\hline Personal Information & Groups & Frequency (f) & Percentage $(\%)$ & $\bar{X}$ \\
\hline \multirow{4}{*}{ AGE } & Between 25-34 & 4 & 9,75 & \multirow{4}{*}{53,26} \\
\hline & Between 35-44 & 4 & 9,75 & \\
\hline & Between 45-54 & 14 & 34,14 & \\
\hline & Between 55-64 & 19 & 46,34 & \\
\hline \multirow{2}{*}{ POSITION } & Club President & 24 & 58,53 & \\
\hline & Vice Chairman & 17 & 41,47 & \\
\hline \multirow{3}{*}{ LENGTH of SERVICE } & Less Than 25 Years & 9 & 21,95 & \multirow{3}{*}{34} \\
\hline & 25-34 Years & 11 & 26,82 & \\
\hline & 35 Years and Above & 21 & 51,21 & \\
\hline
\end{tabular}

Table 1 contains the general information of participants. When the participants in the study group were examined in terms of age groups, the average age was found to be $\% 53,26$ while the highest age interval was found between $\% 46$, 34 and 55-64 years. When we look at the distribution of the duties of the participants, $\% 58,53$ of the club president and 41,47 of the vice president were identified.

When the classifications of the participants were examined according to length service, it was determined that the participant group having the highest rate had between \%51, 21 and 35 years and above. In addition, the average length of service of the participants was determined to be 34 years.

In individual characteristics examined, 25-44 age groups have lowest number of participants in the age category while the managers in the 55-64 age groups have the highest participation rate. It was determined in terms of the distribution of duties that the club presidents have more likely than the vice-presidents. While the lowest participation in terms of service length was found to be those with the duration less than 25 years, the highest participation was provided by those serving over 35 years.

Table 2. How would you describe yourself? Participant Opinions on the Question

\begin{tabular}{llll}
\hline Manager Opinions & f & Manager Opinions & f \\
\hline Supportive & 13 & Instructive & 9 \\
Opposite & - & Learner & 8 \\
Tired & 1 & Patient & 4 \\
Hardworking & 15 & Good Person & 5 \\
Excited & 7 & Hasty & 3 \\
Tolerant & 11 & Stubborn & - \\
Exemplary Person & 3 & Listener & 5 \\
Arrogant & - & Participant & 5 \\
Modest & 4 & Collaborator & 5 \\
\hline
\end{tabular}

When the participants were asked about their views on how they describe themselves, the "hard worker" statement had the highest percentage. Otherwise, "opposite, arrogant and stubborn" statements were not selected by the participants. In terms of frequency of expression, "Supportive" and "Tolerant" expressions are among the most preferred.

Table 3. Participants' Views of the "Change" Category

\begin{tabular}{lll}
\hline S.N & Coded Manager Views & f \\
\hline 1 & Keeping up with innovations & 10 \\
2 & Getting rid of harmful habits & 3 \\
3 & Providing possibility & 5 \\
4 & Importance to infrastructure & 4 \\
5 & Having a flexible structure & 2 \\
\hline
\end{tabular}

Participants were asked whether they wanted to change themselves or not. 14 people answered yes and 14 people answered no and 13 people responded partially.

Some of the participant citations are:

P20: "I wanted to be in a better position by giving importance to infrastructure as infrastructure for us".

VC13: "It is obvious what are going to be done in amateurs, I do not want to change myself".

VC27: "I would like to move forward with more emphasis on science and innovation". 
Table 4. Participants' Views on "what did you gain?" Category

\begin{tabular}{lll}
\hline S.N & Coded Manager Views & f \\
\hline 1 & Nothing & 9 \\
2 & Friendship- Fellowship & 10 \\
3 & Healthy Life & 4 \\
4 & Good Morality & 3 \\
5 & Social Environment & 3 \\
6 & Being Tolerant & 2 \\
7 & Prestige & 2 \\
8 & Income & 5 \\
\hline
\end{tabular}

Participants are asked what they have gained if they think they have given their life to sports, and while Friendship-Fellowship get the highest rate, those saying that they have not gained anything have the second highest rate . Some of the participants' citations are:

B7: "We always gave ourselves up; it is not possible to earn a profit in amateur league".

BY32: "Most important things are friendship and fraternity feelings which exist in sports and are our only gains, also many material-spiritual things can be said additionally".

B33: "If I came back to the world, I would not do sports. We have won nothing".

Table 5. Participants' Opinions in the Category 'What Have You Brought in?"

\begin{tabular}{lll}
\hline S.N & Coded Manager Views & $\mathbf{f}$ \\
1 & Amateur and Professional Athletes & 9 \\
2 & Moral Athletes & 16 \\
3 & Breadwinning & 3 \\
4 & Honesty & 2 \\
5 & Nothing & 3 \\
\hline
\end{tabular}

Participants are asked what they have brought in (gained) if they think they have given their life to sports, and while 'Amateur and Professional Athletes' get the highest rate, there are just 3 people saying that I have not brought in anything. Some of the participants' citations are:

B12: "We provided many young athletes to earn a lot of money. Spiritually, we provided them to gain values such as respect, love, tolerance and take responsibilities at young ages".

BY30: "We tried to keep young people out of bad habits and raised moral athletes".

BY13: "There is nothing in amateur league except to bring Turkish sports in athletes".

\section{Discussion}

Today, there are many projects and studies aimed at the implementation of values education. Particularly in these field studies, trainings such as "teacher assistant program, values education, peer counselling, moral education" which are applied to private schools are noteworthy. In addition, the student can be informed about the values by means of narration, but it is very important and necessary to apply the active teaching methods that students can learn by living, watching and doing like drama so that the student can pass on these values. (Aydın ve Gürler, 2012). Despite all these methods, it seems that educational institutions are inadequate in meeting this demand (Çağlar, 2005). In this context, more dynamic facts are needed about the transfer of values. At this point, the social role of sport plays a key role in meeting the need for value creation and transfer. Bulgu (2013), stated in the study that certain behaviours can be learned by means of sport, in the name of social benefit. It should not be behaviour such as tolerant, modest etc. only during the competition in order to transfer of social values to sport but also it should be a principle to make these values a philosophy of life entirely. In this regard, it is a big importance to discuss all aspects of the duties and understandings of sports managers. First of all, it is necessary to underline the concept of sports manager. According to Uyar and Sunay (2009), the need for sports manager is expressed as follows:

"The sport sector has emerged as a new economic sector that has shown great improvement over time and is called the sports economy The management of the sport sector is now led to the lack of trained staff who are trained in this field, know sports and sportsmen well, can identify the needs and deficiencies of the sector, provide the referrals and management of sports services and activities, anticipate market trends accordingly,"

According to Yetim (1992), a sport manager is one who has all of the qualities that must be found in the modern manager and who, in addition to all these, know sport, management, know the human, sportsman and society, and serve lovingly, willingly and knowingly sacrifice in the direction of the sport management. This and many other similar definitions is that the main focus of sports managers on their professional competence is to become a better manager. However, sports managers are divided into two as official and voluntary in terms of their duties (Biçer, 1994). Although volunteerism in 
this definition is used in the sense of work without pay, it should also be understood as providing the sport to serve social purposes.

Descriptive expressions in Chart 2 show that sports managers have included the definitions of "hardworking, supportive, learner and instructive" in addition to the features of "tolerant, good man, exemplary person" specified in values frame. According to Doğar, a sport manager should know that "sport is not an objective but an important tool in educating people as good citizens through sports" and should try to achieve its goals with this understanding. Just as specified, managers have the ability to transfer a team's values to their coaches, athletes and spectators through sports. Güven (1992) argued that people who are interested in sports have a high level of commitment and interest in social values. At the same time, he stated that sports is beyond the medals and cup that individuals have won, it integrates them into the society as moral, lawful and respectful, peaceful individuals. Having these values alone is not enough but contributing to the transfer of these values is also expected behaviour.

While "keeping pace with innovations" get the highest rate of answers given under the theme of "Change" specified in Chart 3, "enabling" is the expression with the second highest rate. While only $\% 65,85$ of the respondents expressed a positive opinion in supporting change, the other $\% 34,15$ stated that they do not need any change about themselves. The views of supporting or rejecting the change in the managers' statements have been stated to be rationally more successful than the present situation. The main point to note here is that how the refusal or alteration of change should be related to social values? Participants seem to be success-oriented when their views on supporting change are examined. In this sense, there are no expressions such as raising individuals depending on their values, bringing sportsmen in accordance with the "fair play" spirit, and educating honest sportsmen. Should it be called as a positive event in real sense to support change with a utilitarian approach? Argan ve Katıc1 (2008) stated that sports related companies, sporting goods companies, mass media, sports fields, stadiums; companies producing sports commercial products, athletes, professional and amateur leagues have grown into a sporting industry since the 1960s. The concept of amateurism in industrialized sports does not in fact reflect real amateurism. Imamoğlu et al. (2007) stated that amateur athletes are engaged in physical activities without making an interest in obtaining financial gain, and amateur sports clubs are institutions that are aiming to do amateur sports. In this sense, they specified that amateur sports cannot go beyond just sports made for health, and that amateur clubs continue their activities under the name of hidden professionalism. Atasoy and Kuter (2005) pointed of that professional sports have become a phenomenon in the direction of earning money, and that sports volunteers do not exist anymore. Considering that the amateur sports club presidents' and vice-presidents' aim is in the direction of obtaining financial gain in supporting change, it is obvious that having the existing social values alone is not meaningful.

It is noteworthy that there is no such thing as Friendship, Friendship, Good Morality, and Tolerance under the category "What Did You Gain" in Table 4; it is remarkable that they did not earn anything. Because the idea of gaining a high income was dominant in the views of the participants, the number of participant who chose gaining nothing is high.

In Table 5, the category "moral athletes" has the highest rate in the category "What Did You Make Them Gain", and the "amateur and professional athletes", "honesty", and "breadwinning" statements are also striking. Although semi-structured questions are preceded by a descriptive statement such as "If you devoted your life to sport" it was not possible to answer both the earned and the earned values by avoiding economic worries. In this sense, it is not surprising that the concept of change openness is also assessed materially. There are many studies in the literature related to sport that made society gain. Hesapçığlu, 1994 akt. Akandere et al (2009) stated that the purpose of sport is to enable people to form a balanced body structure with a balanced body. Karahüseyinoğlu and Ramazanoğlu (2005) stated that through sport, societies can make the introduction of value judgements that keep them up like their customs and traditions. According to Özel (2009), sports has helped to make many social values that are of great importance, such as dedication, self-sacrifice, fairness, loyalty, responsibility, trustworthiness, tolerance and self-discipline. Aslım (2007) has expressed the sport as an important social activity that helps strengthen the important aspects of the society, including social structure relations, individual and collective identities, values and ideals. Bulgu and Akcan, 2003 akt, Kaplan and Çetinkaya (2014) stated that awareness of the responsibilities of young people after the start of the sport is also an effect of socialization in terms of the importance of sports division of labour, sharing and solidarity, more tolerant to others' opinions and beliefs.

The fact that the value of the society, which is the nature of sports, is interdependent on such a strong foundation, also reveals that the value education is transferred to the individuals without being aware of it through sports. This is the most striking example of the contradictory situation between the acquisition of nothing in the participant expressions and the introduction of moral sportsmen

\section{Results and Suggestions}

In the light of findings obtained from this study, it has been concluded that the president and vice-chairmen of amateur sports clubs have leading values such as dignity, tolerance, communication, love, sharing, and diligence but there are some deficiencies about transferring these values. For this reason, it has come to the conclusion that the role of the sport 
to play a supporting and guiding role on universal and social values can only be realized by the administrators who are conscious, have received a good education and can transfer these values to sportsmen. Moreover, the conscious transfer of social values to sportsmen should not lag behind a number of financial concerns or sporting successes.

The example of the provincial -Ankara, which has limitations in the research, will increase the probability that our results will be supported if it can be extended to include amateur sports clubs all over Turkey. In addition, it may be possible to pass on evaluation of values assessed in all participant dimensions by the inclusion of coaches and athletes also. Besides, behavioural developments for gains can be provided through trainings aimed at educating managers about values education.

\section{References}

Acun, İ., Yücel, C., Önder, A., \& Tarman, B. (2013). Values: How Much Value Does It Give? Usak University Journal of Social Sciences, 2013(12).

Akandere, M., Aslan, F., Boyali, E., \& Kaya, E. (2005). An Analysis of Problem Solving Skills of Youth Who Do and Do not Play in Universities, 4th National Physical Education and Sports Teacher Symposium.

Akbaş O. (2008). An Overview of Value Education Flows. Values Education Journal, 6(16), 9-27.

Argan, M., \& Katırc1, H. (2008). Sports Marketing (2nd Edition). Ankara: Nobel Publication Distribution.

Aslım, M. (2007). A Comparative Study on the Function of Sports in Modern Society. Gazi University Institute of Social Sciences Department of Sociology Master Thesis

Atasoy, B., \& Kuter, F. Ö. (2005). Globalization And Sports. Uludağ University Journal of Education, Journal XVIII(1), $11-22$.

Aydın, M. Z., \& Gürler, Ş. A. (2012). Values Education in School. Ankara: Nobel Publication Distribution.

Balcı, F. A., \& Yelken, T. Y. (2010). Meaning of primary school teachers' concept of "value". Hacettepe University Journal of Education, 39(39).

Bicer, T. (1994). Sports Management Organization An Example from Sports Operations and Practice as an Economic Unit, Unpublished Doctorate Thesis, Mü Sos. Know. Enst. Management Organization Abd, İstanbul.

Bulgu, N. (2013). Community Participation in Sports: Kazakhstan Ahmet Yesevi University Student Example. Hütad, (18).

Caglar, A. (2005). New Approaches in Early Childhood Development and Education. Publication prepared by: Müzeyyen Sevinç. Values Education in Preschool Period. Istanbul: Morpa Culture Publications.

Elbir, B., \& Bağc1, C. (2013). Assessment of Postgraduate Level Studies on Values Education / Postgraduate Theses on Values Education. Turkish Studies - International Periodical For Languages, Literature and History of Turkish or Turkic, 8,1 .

Genç, S. Z., \& Eryaman, M. Y. (2008). Variable Values And Paradigm of New Education. Journal of Social Sciences, 9(1), 89-102.

Imamoglu, A. F., Karaoglu, E., \& Erturan, E. (2007). Structural Qualities and Main Problems of Sports Clubs in Turkey.

Kafadar, O. (2002) Kocabaşoğlu, U. (Ed.), Modernization and Westernism in Contemporary Turkish Education Discussions, Political Thought in Modern Turkey, 3, 351-381. Istanbul: Communication Publications.

Kaplan, Y., \& Cetinkaya, G. (2014). Socialization through Sports - Re-socialization Process. International Journal of Science Culture \& Amp; Sport, 2, 120-125. https://doi.org/10.14486/IJSCS183

Karahüseyinoğlu, M. F., Ramazanoğlu, M. O., Demirel, E. T., Altungül, O., \& Ramazanoğlu, F. (2005). Evaluation of social dimensions of sport.

Kerschensteiner, G. (1954). Character Concept and Character Rate (By H. F. Kanad). Ankara: Sample Printer.

Keten, M. (1974). Sport in Turkey. Ayyıldız Matbaası, 14(19), 21, Ankara.

Köybaşı, F., \& Dönmez, B. (2012). Opinions of Newly Started And Retired Elementary School Teachers on Professional Values and Investigation of Changes in These Values. Theory \& Practice - 12 (2) [Supplementary Special Issue] Spring / Spring 1379-1396.

Lickona, T. (1991). Educating for character: How schools can teach respect and responsibility. New York, Bantam Books, 6-22.

Öcalan, M., \& Ramazanoğlu, F. (2003). An Investigation of the Frequencies of Footballers Watching According to 
Some Demographic Characteristics. G.Ü. Physical Education and Sporda Social Fields Congress, Ankara 10- 11 October.

Samur, A. Ö. (2011). The Impact of Values Education Program on Social and Emotional Development of 6 - Year - Old Children (Doctoral Dissertation, Institute of Social Sciences, Selcuk University).

Şebin, K., Tozoglu, E., Yilmaz, S., Demirel, N., \& Bostanc1, Ö. (2010). Opinions of University Students Who Play Sports on Fertility Play. Journal of Physical Education And Sport Sciences, 9(2), Retrieved From http://Dergipark.Gov./Ataunibesyo/issue/2415/30730

Special A. (2009). The Impact of Sports on the Education of Street Children. T.C. Beykent University Graduate School of Social Sciences Department of Business Administration Department of Educational Administration and Supervision Department of Science.

Trust, Ö. (1922). Sports Understanding and Socioeconomic Function of Sports, Gazi Education Faculty Journal, 8(1), 35.

Ulusoy, K., \& Dilmaç, B. (2012). Values education. Ankara: Pegem A Academy.

Uyar, Y., \& Sunay, H. (2009). A Research on the Perception Levels of University Sports Management Training by the Ankara Sporting Public Opinion Sportsmeter Journal of Physical Education and Sport Sciences, VII(4) 141-149.

Yetim, A. (1992) Characteristics of a Successful Sports Manager G.Ü. Gazi Education Faculty. Journal, 8(1), 14.

Yiğittir, S., \& Ocal, A. (2011). High School History Teachers' Opinions on Values and Values Education.

Yıldıran, İ. (2005). The Role of Physical Education in Fair Play Education. Journal of Gazi Physical Education and Sports Sciences, 5(1), 3-16.

Yıldırım, Ş. H. (2011). Qualitative Research Methods In The Societal Scics. Selective Publishing.

\section{Copyrights}

Copyright for this article is retained by the author(s), with first publication rights granted to the journal.

This is an open-access article distributed under the terms and conditions of the Creative Commons Attribution license which permits unrestricted use, distribution, and reproduction in any medium, provided the original work is properly cited. 